\title{
PERAN STAKEHOLDER LEMBAGA PENDIDIKAN DALAM USAHA MENUMBUHKAN JIWA WIRAUSAHA DIKALANGAN MAHASISWA ( STUDI KASUS MAHASISWA JURUSAN MANAJEMEN PADA PERGURUAN TINGGI DI KABUPATEN KARAWANG )
}

Citra Savitri ${ }^{1)}$,EnjangSuherman ${ }^{2)}$, Suroso $^{3)}$,

FakultasBisnis dan IlmuSosial, UniversitasBuanaPerjuanganKarawang

Citra_Savitri@ubpkarawang.ac.id

FakultasBisnis dan IlmuSosial, UniversitasBuanaPerjuanganKarawang

Enjangsuherman@ubpkarawang.ac.id

FakultasBisnis dan IlmuSosial, UniversitasBuanaPerjuanganKarawang

Suroso@ubpkarawang.ac.id

\begin{abstract}
Abstrak
Penelitian ini bertujuan untuk membuktikan peran para stakeholder beserta kendala yang hadapai lembaga pendidikan dalam usaha menumbuhkan jiwa berwirausaha di kalangan mahasiswa jurusan Manajemen pada Perguruan Tinggi di Karawang

Metode penelitian dengan mengumpulkan data dalam penelitian ini melalui instansi atau lembaga yang berkaitan dan website yang relevan dengan pokok bahasan yaitu kewirausahaan, kemudian di analisis dengan menggunakan Focus Group Discussion ( FGD ) dan wawancara khusus pada para Stakeholder dalam Lembaga Pendidikan di daerah Kabupaten Karawang dikhususkan pada Jurusan Prodi Manajemen.

Hasil penelitian ini menunjukan bahwa terdapat peran stakeholder perguruan tinggi prodi manajemen kabupaten karawang dalam upaya meningkatkan jiwa wirausaha mahasiswa melalui: (a) Kurikulum Pendidikan Program Studi; (b) Program Mahasiswa Kewirausahaan; (b) Metode Pembelajaran Kewirausahaan; (c) Pelatihan Kewirausahaan Mahasiswa; (d) Kerjasama Lambaga dalam kewirausahaan. Namun terdapat kendala kegiatan tersebut yaitu (a) Partisipasi Mahasiswa; (b) Pola Pikir Mahasiswa; (c) Modal Usaha Awal; (d) Biaya Kegiatan Kewirausahaan; (e) Inkubator Bisnis
\end{abstract}

Kata Kunci : Peran Stakeholders, Jiwa berwirausaha, Mahasiswa.

\section{Abstract}

This Reseach aims to prove the role of stakeholders and the obstacles faced by educational institutions in an effort to foster entrepreneurship among students majoring in Departement of Management at collages at Karawang. The research method is by collecting data in this reseach through relevant institutions and websites that are relevant to the subject matter, namely entrepreneurship, then analyzed using Focus Group Discussion (FGD) and special interviews with stakeholders in educational institutions in the Karawang specifically in Department of Management Study Program.

The results of this reseach indicate that there is a role of stakeholders in Department of Management Study Program educational institutions at Karawang an effort to improve the spirit of student entrepreneurship through: (a) Education Curriculum for Study Programs; (b) Entrepreneurship Student Program; (b) Entrepreneurship Learning Methods; (c) Student Entrepreneurship Training; (d) Cooperation of Institutions in entrepreneurship. But there are obstacles to these activities, namely (a) Student Participation; (b) Student Mindset; (c) Initial venture capital; (d) Activities Costs of Entrepreneurship; (e) Business Incubator.

Keywords: Role of Stakeholders, Soul of Entrepreneurship, Students 


\section{PENDAHULUAN}

Berwirausaha merupakan salah satu upaya yang dapat membantu pemerintah dalam rangka mengurangi pengangguran dan tingkat kemiskinan serta memiliki peranan penting dalam upaya percepatan pertumbuhan suatu negara. Berwirausaha bukan hanya mampu untuk menyerap tenaga kerja secara maksimal tetapi juga mampu menaikkan nilai pendapatan nasional, meningkatkan hasil produksi lebih baik, memberikan peluang untuk menambah penghasilan lebih baik, mengurangi tingkat kriminalitas, kesenjangan sosial dan banyak lagi, yang bisa sebagai penyumbangan pembangunan suatu daerah.

Tercatat jumlah penduduk Indonesia adalah sebesar 260 juta jiwa (BPS, 2012). Jumlah penduduk yang banyak diharapkan mampu bersaing di di dalam maupun luar negeri. Hal ini dikarenakan Indonesia memiliki potensi yang strategis jika dipandang sebagai potensi pangsa pasar bagi dunia industri. Di samping itu jika potensi keterampilan yang dimiliki setiap SDM tersebut dapat dikelola dan dikembangkan, maka hal tersebut bisa menjadi kekuatan yang besar bagi pembangunan negara dan posisi tawar di mata dunia. Mahasiswa adalah generasi muda diharapkan mampu untuk membuat berbagai kegiatan diantaranya yaitu menciptakan usaha sendiri dan mahasiswa merupakan salah satu tonggak keberhasilan tujuan negara, karena ditangan kaum mudalah keberhasilan pertumbuhan ekonomi negara bergantung.

Dilihat jumlah hasil kelulusan setiap tahunnya selalu meningkat seiring dengan pertambahan jumlah penduduk. Namun hal tersebut tidak berpengaruh terhadap jumlah pengangguran yang ada. Hal tersebut terjadi karena kebanyakan mahasiswa ketika lulus kuliah hanya ingin menjadi seorang pegawai atau melamar sebagai pegawai (karyawan ) dan hanya sebagian kecil saja yang ingin berwirausaha. Ini menggambarkan betapa pola pikir untuk menjadi wirausaha di kalangan mahasiswa masih sangat kecil. Fenomena tersebut terjadi karena minimnya pengetahuan SDM tentang pentingnya dan peran besar berwirausaha bagi dirinya sendiri maupun untuk negara.

Dunia pendidikan merupakan salah satu wadah yang paling tepat untuk membantu SDM dalam rangka menumbuhkan jiwa berwirausahan, terutama dikalangan mahasiswa. Hendarman dalam Siswoyo (2009) menyatakan bahwa semakin tinggi pendidikan seseorang semakin rendah kemandirian dan semangat kewirausahaannya. Untuk itu Lembaga pendidikan salah satunya perguruan tinggi diharapkan senantiasa membangun dan mengarahkan kemampuan serta minat para lulusannya untuk bergerak dan mengembangkan kewirausahaan sehingga para lulusan tidak bergantung pada banyaknya jumlah lapangan pekerjaan tetapi mereka mampu untuk menciptakan lapangan kerja sendiri.

Pentingnya dukungan Lembaga Pendidikan jika tidak di bantu oleh Pemerintah pastinya akan mengalami hambatan dalam upaya menumbuhkan dan membangun jiwa berwirausaha dikalangan mahasiswa. Maka Pemerintah pun memberi dukungan dengan dibuatnya program pengembangan kewirausahaan di kalangan perguruan tinggi. Salah satu bentuknya adalah melalui Direktorat Jendral Pendidikan Tinggi, pemerintah menyelenggarakan Program Mahasiswa Wirausaha dengan memberikan bantuan atau hibah yang dapat dipergunakan oleh mahasiswa dan dosen pembinanya untuk mengembangkan suatu bisnis tertentu. Program tersebut dibuat diharapkan setelah bisnis tersebut berkembang akan memiliki dampak yang berkelanjutan dalam pengembangan bisnis selanjutnya oleh mahasiswa lainnya. Mampu untuk mengurangi masalah ekonomi yang terjadi, seperti masalah pengangguran pada lulusan perguruan tinggi. Kerjasama yang 
baik antara Pemerintah dan Lembaga pendidikan juga sangat berperan penting demi terlaksananya program beasiswa berwirausaha dikalangan mahasiswa. Lembaga-lembaga pendidikan tersebut antara lain : Sekolah Formal dan Informal, Perguruan tinggi dan lainlain.

Saat ini wirausaha merupakan salah satu penyokong pertumbuhan ekonomi yang paling efektif dan merupakan motor penggerak perekonomian. Salah satu sasaran paling tepat adalah mahasiswa/i dalam upaya peningkatan program padat karya. Namun pada kenyataannya minimnya kemampuan sumber daya manusia seperti kurangnya keterampilan, rendahnya kreativitas, inisiatif, tingkat pendidikan, pengaruh kuat lingkungan, terbatasnya informasi, pemenuhan teknologi seringkali menjadi kendala bagi Lembaga-lembaga pendidikan untuk upaya menumbuhkan jiwa kewirausahaan pada mahasiswa, tidak terkecuali mahasiswa/i jurusan Manajemen di lingkungan Perguruan Tinggi Karawang. Apabila setiap Stakeholder dalam Lembaga-lembaga pendidikan seperti dilingkungan Perguruan Tinggi Karawang mampu untuk bekerja sama dengan baik untuk bisa menumbuhkan jiwa berwirausaha dikalangan mahasiswa maka hal tersebut dapat berdampak pada pendapatan individu mahasiswa tersebut dan secara langsung dapat berpengaruh pada peningkatan ekonomi masyarakat serta peningkatan kualitas SDM lalu berdampak juga pada Multieffect pendapatan daerahnya.

Kreativitas dan inovasi merupakan modal awal dalam menumbuhkan minat berwirausaha. Pembahasan fokus terhadap permasalahan Tingkat kelulusan yang semakin tinggi di perguruan tinggi sedangkan lapangan pekerjaan yang tidak terlalu banyak akan menimbulkan pengguran. Oleh sebab itu peran Lembaga dibutuhkan dalam mencetak calon wirausaha dikalangan mahasiswa dengan menumbuhkan jiwa wirausaha mahasiswa, yaitu fokus penelitian antara lain:

a. Bagaimana peran Lembaga Pendidikan dalam usaha menumbuhkan jiwa berwirausaha di kalangan mahasiswa jurusan Manajemen pada Perguruan Tinggi di Kabupaten Karawang?

b. Bagaimana mengidentifikasi kendala yang dihadapi para stakeholder lembaga pendidikan dalam rangka meningkatkan kemampuan jiwa berwirausahan mahasiswa jurusan Manajemen pada Perguruan Tinggi di Kabupaten Karawang?

Penelitian ini bertujuan untuk: (1) Mengetahui peran para stakeholder dalam Lembaga Pendidikan dalam usaha menumbuhkan jiwa berwirausaha dikalangan mahasiswa jurusan Manajemen pada Perguruan Tinggi di Kabupaten Karawang; (2) Mengetahui kendala yang dihadapi para stakeholder lembaga pendidikan dalam rangka meningkatkan kemampuan jiwa berwirausahan mahasiswa jurusan Manajemen di lingkungan Perguruan Tinggi di Kabupaten Karawang

\section{LANDASAN TEORI}

\section{JIWA WIRAUSAHA MAHASISWA}

Menurut Schumpeter dalam Alma (2010) menyatakan bahwa wirausaha adalah orang yang mendobrak system ekonomi yang ada dengan memperkenalkan barang dan jasa yang baru dengan menciptakan bentuk organisasi baru atau mengolah bahan baku. Pendapat lain datang dari Dr.Kasmir, M.M,(2014:20) menyatakan bahwa kewirausahaan merupakan suatu kemampuan dalam halmenciptakan kegiatan usaha. Kemampuan menciptakan memerlukan adanya kreativitas dan inovasi yang terus-menerus untuk menemukan sesuatu 
yang berbeda dari yang sudah ada sebelumnya. Kreativitas dan inovasi tersebut pada akhirnya mampu memberikan kontribusi bagi masyarakat banyak. Kesuksesan dalam berwirausaha bukanlah didapat dalam waktu yang singkat, tetapi semua itu didapatkan lewat proses. Hal tersebut terjadi jika seseorang komitmen terhadap apa yang dicita-citakan dengan tetap memegang teguh etika dalam berbisnis.

Disimpulan bahwa wirausaha merupakan proses seseorang dalam mengunakan, memanfaatkan peluang, menciptakan, dan menerapkan sesuatu berdasarkan dari kemampuan dalam memberikan pelayanan secara maksimal, berinovasi, berkreativitas tinggi dalam upaya untuk memperoleh keuntungan secara efektif dengam menerima resiko yang akan di terimanya serta balas jasa yang akan didapatkan dari pekerjaanya.

Jiwa wirausaha merupakan perasaan, pikiran dan angan-angan seseorang untuk mencari sumber penghasilan dengan mengembangkan ide dan kreatifitas yang dimilikinya. Jiwa berwirausaha seseorang akan terus tumbuh ketika seseorang mulai sadar bahwa uang merupakan hal penting dan tersadar bahwa kreatifitas yang dimilikinya dapat terus dikembangkan untuk berfikir secara kritis, mandiri dan ingin maju. Seseorang yang terus mengembangkan jiwa berwirausaha akan terus berfikir bahwa apapun yang didapat adalah sebuah pembelajaran untuk terus menggali kemampuannya dan akan menghasilkan sebuah karya yang dapat bermanfaat bukan hanya untuk dirinya sebagai produsen tetapi juga bagi konsumen yang menikmati hasil karyanya.

\section{PERAN STAKEHOLDER LEMBAGA PENDIDIKAN}

Lembaga Pendidikan merupakan tempat bagi setiap orang untuk melaksanakan proses pendidikan, penelitian, pusat kegiatan dan keterampilan. Perguruan tinggi merupakan salah satu lembaga pendidikan formal yang memiliki peran dan posisi strategis dalam upaya mewujudkan sumber daya manusia yang berkualitas.

Ada beberapa fungsi Lembaga Pendidikan yang dapat memberikan pengaruh bagi seseorang dalam upaya peningkatan kualitas dirinya, antara lain : (a) Mengembangkan kecerdasan pikiran dan memberikan pengetahuan kepada anak didik; (b) Spesialisasi dalam bidang pendidikan dan pengajaran; (c) Efisiensi.

Pentingnya Lembaga pendidikan dalam kehidupan sehari-hari maupun dalam dunia pendidkan sangat berdampak bagi kemampuan setiap orang untuk menjadi seseorang yang memiliki kompetensi lebih baik dari sebelumnya. Berikut adalah peran penting Lembaga Pendidikan yaitu : (a) Mendidik, mengajar, serta memperbaiki tingkah laku anak didik; (b) Sarana belajar bergaul mempersiapkan anak didik untuk menjadi anggota masyarakat yang berguna bagi agama, bangsa, dan negara.

Stakeholder memiliki hubungan yang sangat erat dalam sebuah lingkungan dan memiliki peranan dalam menjaga kerangka kebijakan, melaksanakan serta pengambilan keputusan dalam sebuah perusahaan (lembaga pendidikan ) dalam upaya mencapai tujuan perusahaan tersebut

Upaya untuk menumbuhkan jiwa wirausaha bagi mahasiswa sangat diperlukan.

Ketika mahasiswa sudah menyelesaikan studi diperguruan tinggi, mahasiswa dapat membuka lapangan pekerjaan sendiri tidak tergantung kepada lowongan pekerjaan. Seperti hanya penelitian yang dilakukan oleh Bambang Bayu Siswoyo dalam jurnal ekonomi bisnis nomor 2 Fakultas Ekonomi Universitas Negeri Malang (2009) menyatakan bahwa kewirausahaan menjadi sangat penting untuk menciptakan kesempatan bagi masyarakat, mengembangkan orang-orang. Disamping itu mahasiswa dan dosen dapat dikembangkan jiwa kewirausahaanya dengan cara program praktik wirausaha, pelatihan kewirausahaan, 
kuliah kewirausahaan secara teratur, kuliah kerja nyata-usaha, konsultasi bisnis, magang kewirausahaan, dan wirausaha baru dengan pendampingan.

Dengan demikian penulis dapat melakukan penelitian yang lebih mendalam dengan melibatkan unsur stakeholder lembaga pendidikan dalam menumbuhkan jiwa wirausaha bagi kalangan mahasiswa.

\section{METODE PENELITIAN}

Penelitian ini dilakukan dengan menggunakan desain penelitian kualitatif berupa studi kasus dengan mengkaji mendalam tentang individu atau kelompok dari suatu kegiatan dalam waktu tertentu. Tujuannya untuk memperoleh diskrisi yang utuh dan mendalam dari sebuah entitas.

Lokasi penelitian akan dilakukan di perguruan tinggi baik swasta atau negeri di kabupaten karawang yang mempunyai prodi manajemen seperti Universitas Singaperbangsa Karawang, Universitas Buana Perjuangan Karawang, STIE Pertiwi, dan STIE Yayasan Pendidikan Nusantara

Peran Stakeholder lembaga pendidikan memiliki peranan dalam menjaga kerangka kebijakan, melaksanakan serta pengambilan keputusan dalam sebuah perusahaan (lembaga pendidikan ) dalam upaya mencapai tujuan organisasi tersebut.

Jiwa kewirausahaan mahasiswa merupakan jiwa kemandirian untuk membukan lapangan usaha dengan menyalurkan kreatifitas mahasiswa sehingga menjadi sumber penghasilan

Adapun model yang digunakan dalam penelitian ini dengan menggunakan diskusi kelompok terarah yang bertujuan memperoleh data informasi yang komperhensip tentang permasalah yang diteliti.

Teknik pengumpulan data menggunakan teknik wawancara dan observasi dengan diskusi kelompok mahasiswa. Kelompok tersebut terdiri dari; (1) Universitas Singaperbangsa Karawang (prodi manajemen); (2) Universitas Buana Perjuangan (prodi manajemen); (3) STIE Pertiwi (prodi manajemen); (4) STIE YPN (prodi manajemen). Masing-masing kelompok terdiri dari $4-7$ orang secara random, beserta dengan para stakeholder lembaga pendidikan tersebut.

Analisis yang digunakan adalah Focus Group Discussion ( FGD ) dengan mengkaji berupa data dan informasi kendala- kendala yang dihadapi dalam upaya menumbuhkan jiwa berwirausaha dikalangan mahasiswa serta rekomendasi usaha yang dapat dilakukan untuk menumbuhkan jiwa berwirausaha dikalangan mahasiswa menurut persepsi para Stakeholder dan mahasiswa.

Analisis data dan penulisan laporan FGD dengan langkah-langkah sebagai berikut: (1) Mendengarkan atau melihat kembali rekaman FGD; (2) Tulis kembali hasil rekaman secara utuh (membuat transkip); (3) Baca kembali hasil transkip; (4) Cari masalah/topik yang menonjol, kelompokan menurut topik; (5) Buat koding dari hasil transkrip menurut pengelompokan topik/masalah; (6) Penulisan pembahasan.

\section{HASILDAN PEMBAHASAN}

a. Peran Lembaga Pendidikan Dalam Usaha Menumbuhkan Jiwa berwirausaha Mahasiswa 
Pendidikan merupakan salah satu dasar untuk menghasilkan para calon pemimpin yang berkompeten. Perguruan Tinggi merupakan salah satu lembaga penghasil sumberdaya potensial bagi sebuah Negara. Semakin banyak sumberdaya manusia yang berkompetensi tentunya akan berdampak pada peningkatan pembangunan Negara.

Lembaga pendidikan merupakan salah satu bagian terpenting bagi kemajuan bangsa dalam menciptakan tenaga kerja potensial. Dalam menciptakan sumber daya kompeten sangat bergantung pada penentuan kurikulum yang dibuat oleh perguruan tinggi tersebut. Perguruan Tinggi sebagai salah satu pusat pembinaan dan pengembangan kewirausahaan ditetapkan melalui hasil pertemuan wilayah Asia dan Pasifik "APEC" di Seatle sebagaimana salah satu agenda kesepakatan bahwa untuk membantu mempercepat pertumbuhan perekonomian di wilayah Asia Pasifik secara luas dan merata, perlu adanya kerjasama "tripartite" antara "Government Business Universities", Sanusi ( 2005:77) dalam Peranan Perguruan Tinggi dalam Mengembangkan Sikap Mental Kewirausahaan Mahasiswa (Lia Yuliana, 2012).

Kewirausahaan merupakan salah satu upaya yang terus dilakukan pemerintah dalam mengurangi jumlah pengangguran. Usaha menumbuhkan jiwa berwirausaha merupakan langkah awal yang dilakukan Lembaga Pendidikan, seperti membantu mahasiswa menciptakan sebuah peluang baru dari kreatifitas dan inovasi yang dimiliki. Menjadi sebuah kewajiban bagi Perguruan Tinggi untuk menggali potensi diri setiap mahasiswa dengan berbagai cara. Bukan hanya sekedar memberikan motivasi secara personal tetapi berbagai upaya menumbuhkan jiwa wriausaha untuk setiap mahasiswanya yang telah dilakukan Perguruan Tinggi yang ada di Kabupaten Karawang antara lain Universitas Singaperbanga Karawang, Universitas Buana Perjuangan Karawang dan STIE YPN.

Berbagai program yang telah dilakukan Perguruan Tinggi dalam usaha menumbuhkan jiwa berwirausaha di Kalangan mahasiswa, antara lain program Gebyar Kewirausahaan, Market Day, Seminar Kewirausahaan, Pelatihan Kewirausahaan, keikutsertaan dalam PKM (Program Kreatifitas Mahasiswa bidan Kewirausahaan) yang menuntut mahasiswa dalam menciptakan sebuah produk baru atau inovasi berbagai jenis produk yang berbeda. Namun mampu bersaing dipasar sasaran.

Perguruan Tinggi merupakan salah satu wadah yang paling tepat bagi mahasiswa dalam mendapatkan berbagai informasi yang dibutuhkan. Perguruan Tinggi akan menumbuhkan nilai-nilai kepemimpinan sebagai modal dalam membangun sebuah usaha serta membentuk mental seorang wirausaha yang baik bagi mahasiswa. Berbagai program yang diberikan Perguruan Tinggi diharapkan mampu menstimulus mahasiswa, tidak hanya sekedar memiliki wawasan tentang wirausaha saja tetapi juga kemampuan dalam mengembangkan dan meningkatkan kualitas serta jangkauan berwirausaha. Bentuk lain yang diberikan Stakeholder dalam usaha menumbuhkan jiwa wirausaha antara lain turut serta dalam setiap kegiatan yang dilaksanakan oleh mahasiswa sebagai salah satu bagian dari Tridharma bidang Penelitian melalui pendampingan dalam penyusunan proposal PKM Kewirausahaan yang bertujuan untuk mengasah kemampuan mahasiswa dalam menggali kemampuan untuk memperluas pengetahuan dibidang kewirausahaan sebagai nilai tambah berbisnis.

Usaha menumbuhkan jiwa wirausaha mahasiswa tidak bisa berjalan sendrinya tanpa ada pihak yang membatu seperti Stakeholder. Stakeholder memiliki hubungan yang sangat erat dalam sebuah lingkungan dan memiliki peranan dalam menjaga kerangka kebijakan, melaksanakan serta pengambilan keputusan dalam sebuah perusahaan (lembaga 
pendidikan ) dalam upaya mencapai tujuan lembaga tersebut. Pemangku kepentingan atau stakeholder dalam perguruan tinggi yang berpengaruh dan dipengaruhi untuk menumbuhkan jiwa wirausaha secara langsung meliputi pimpinan perguruan tinggi seperti Senat dan jajarannya, ketua program studi, dosen pengampu matakuliah kewirausahaan serta mahasiswa sendiri sebagai pemangku kepentingan.

Kewirausahaan merupakan salah satu media bagi mahasiswa untuk meluaskan cara pandang dan mengembangkan kreatifitas serta inovasinya, sehingga mahasiswa tidak perlu lagi terpaku kepada salah satu bidang untuk pekerjaan menjadi pilihan profesinya di masa depan. Dengan kewirausahaan, mahasiswa dapat menerapkannya di segala bidang pekerjaan dan kehidupan.

Era revolusi industri 4.0 menunjukan tingginya kemajuan teknologi saat ini, kreatifitas dan inovasi menjadi salah satu alasan bagi setiap sumber daya untuk meningkatkan softskill yang dimiliki, salah satunya jiwa kewirausahaan, mahasiswa dilatih untuk memiliki tanggung jawab atas resiko keputusan yang diambil dalam berwirausaha. Berlatih untuk bersikap jujur dan komitmen sehingga usaha yang dijalankan mampu bersaing secara kompetitif.

Salah satu peran dalam menumbuhkan jiwa wirausaha bagi kalangan mahasiswa terutama prodi manajemen meliputi:

\section{1) Kurikulum Pendidikan Program Studi}

Pada program studi manajemen dalam upaya menumbuh kembangkan jiwa berwirausaha terdapat beberapa mata kuliah yang diberikan antara lain : mata kuliah kewirausahaan, perencanaan bisnis, pengembangan bisnis, etika dan komunikasi bisnis, pengantar bisnis dan pengantar manajemen sebagai dasar dalam memulai usaha baru.

Program studi dalam kurikulumnya mewajibkan setiap mahasiswa mengambil mata kuliah entrepreneurship dan membuat business plan sebagai keluaran dari mata kuliah tersebut. learning outcome mahasiswa dapat memiliki jiwa kemandirian dalam mencari penghasilan melalui kreatifitas dan inovasi dalam membuka suatu ladang usaha.

Pengampu untuk setiap matakuliah yang berhubungan dengan kewirausahaan, Lembaga khususnya prodi manajemen menunjuk dosen berkualitas sesuai dengan bidang ilmu. Latar belakang keilmuan dan pengalaman yang mumpuni untuk praktisi dibidang wirausaha menjadi kunci utama dalam penunjukan dosen pengampu matakuliah tersebut.

Dosen pengampu memerlukan penguatan kompetensi melalui pelatihan, seminar, workshop, dan uji sertifikasi kompetensi. Pembekalan kompetensi bagi dosen untuk meningkatkan kualitas mengajar dan membekali diri sendiri untuk memahami keterampilan yang dimiliki untuk disalurkan kepada mahasiswa terutama bagaimana menumbuhkan jiwa wirausaha.

Pada hakikatnya jiwa wirausaha sudah ada ditanamkan kepada mahasiswa ketika memasuki dunia Pendidikan baik formal maupun informal. Seperti contoh berorientasi ke masa depan, seorang pelajar/mahasiswa memutuskan untuk melanjutkan pendidikan tujuannya untuk memiliki pengetahuan sehingga memiliki kehidupan yang lebih baik. Orientasi ke masa depan tersebut merupakan salah satu karakter dari jiwa seorang wirausahawan.

\section{2) Program KewirausahaanMahasiswa}


Stakeholder berperan dalam membantu menumbuhkan jiwa wirausaha mahasiswa. Kampus banyak menjalin kerjasama dengan para stakeholder dalam program-program yang mendukung geliat tumbuhnya jiwa wirausaha mahasiswa.

Berbagai upaya yang dilakukan oleh stakelohder dalam meningkatkan animo mahasiswa untuk berwirausaha sedari dini, antara lain program kreatifitas mahasiswa melalui PKM, kegiatan market day atau kegiatan Gebyar Kewirausahaan, mengadakan Seminar Nasional dengan mendatangkan pemateri yang memang berkompeten dibidang kewirausahaan, pendampingan dalam berwirausaha dengan dinas terkait ( Dinas Koperasi dan UMKM dan Dinas Perindustrian ) serta ikut serta dalam pagelaran nasional yang diadakan dinas terkait, pengajuan PIRT produk karya cipta mahasiswa.

Program Kreatifitas Mahasiswa atau disebut PKM merupakan program yang diselenggarakan oleh Direktorat Jendral Pendidikan Perguruan Tinggo atau DIKTI yang memeberikan kesempatan kepada mahasiswa untuk mengembangkan kreatifitasnya. Tujuan adanya PKM diharapkan dimasa depan mahasiswa dapat menjadi anggota masyarakat yang mempunyai kemampuan akademik, dan mengembangkan atau penyebaran ilmu pengetahuan dan teknologi. Pengembangan PKM untuk mengembangkan kreatifitas dan inovasi mahasiswa melalui keilmuan berdasarkan sains dan teknologi. Mahasiswa dibimbing oleh salah satu dosen untuk membuat suatu produk yang diajukan ke dikti. Salah satu poduk PKM meliputi PKM Penelitian, PKM Kewirausahaan, PKM Pengabdian Masyarakat, PKM Penerapan Teknologi dan PKM Artikel Ilmiah. PKM Kewirausahaan merupakan produk unggulan yang sering diusulkan setiap tahun. Sedangkan produknya dipamerkan di market day dan kegiatan gebyar kewirausahaan.

Maket day atau gebyar kewirausahaan merupakan program kewirausahaan upaya untuk membangun dan menumbuhkan jiwa kewirausahaan. Program gebyar kewirausahaan merupakan gambaran mengenai bagaimana memberikan kontribusi sebanyak mungkin bagi perkembangan kewirausahaan dan UMKM di kalangan mahasiswa. Melalui kegiatan PKM mahasiswa dapat menggali kemampuan bukan hanya secara akademik tetapi juga kemampuan berfikir secara kritis, kemampuan dalam berkomunikasi dan berbisnis(Citra, Wanta;2017). Mahasiswa akan langsung bisa merasakan secara langsung atau mengalami proses wirausaha mulai dari persiapan produk sampai ke pemasaran ke pembeli. Program gebyar kewirausahaan diharapkan memeberikan kontribusi kepada mahasiswa berupa terbangunya kemampuan dan keterampilan seperti implementasi pemasaran produk, persiapan produk siap jual, dan jiwa kewirausahaan tertanam di diri mahasiswa seperti keneranian, percaya diri, keuletan dan sebagainya.

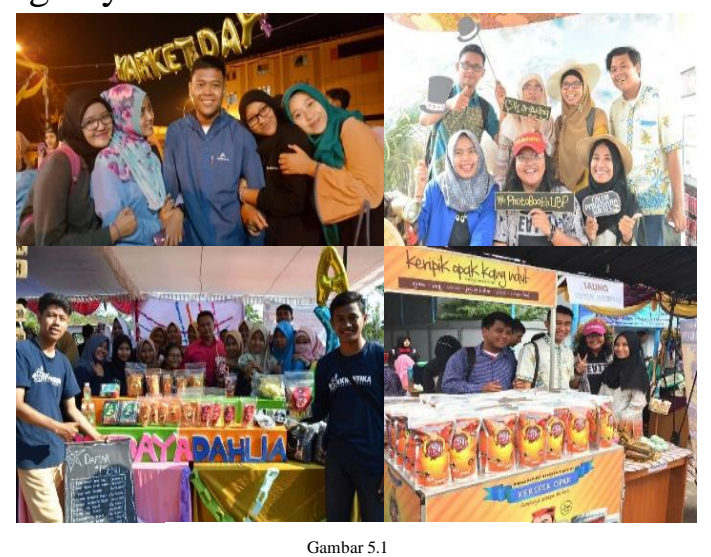


Dunia wirausaha dapat tergambarkan dalam sebuah acara seminar, gambaran tersebut bagaimana mengetahui jenis usaha yang memiliki prospek yang menguntungkan. Seminar juga akan memberikan pengetahuan baru, terutama mencari penyelesaian atas permasalahan dalam kegiatan wirausaha, selain itu juga, seminar kewirausahaan akan memberikan motivasi kepada para peserta seminar sehingga jiwa wirausahanya bangkit dan ingin memulai usaha. Tujuan lain dari seminar kewirausahaan ini untuk para mahasiswa yang sudah lulus nantinya tidak terpaku pada lapangan kerja, melainkan menciptakan lapangan kerja baru untuk pencari kerja lainnya.

Pencetakan wirausahawan kreatif dan inovatif tentu tidak bisa dengan cara sederhana. Setidaknya seminar kewirausahan dapat mendapatkan ilmu dari para materi yang berpengalaman. Para materi yang hadirkan merupakan para usahawan-usahan muda yang sukses dalam usahanya, diharapkan para materi menjadi contoh supaya mahasiswa dapat merintis usaha yang akan dijalan sesukses para materi tersebut. Para materi dalam menjalankan usahanya mulai dari nol sampai suskses diwaktu muda dengan keuletan, keberanian, percaya diri, kreatif, inovatif, kemandirian, memperhitungkan serta mengambil resiko dan strategi menjadi pemicu jiwa kewirausahaan bangkit dan memulai usaha.

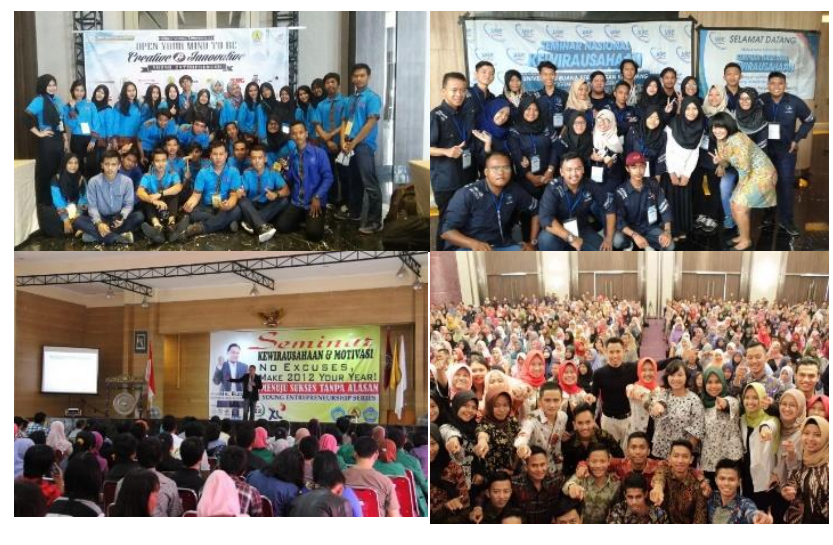

Gambar 5.2 Seminar NasionalKewirausahaan

\section{3) Metode PembelajaranKewirausahaan}

Pembelajaran bukan sekedar transfer ilmu dari dosen ke mahasiswa namun penanaman kebiasaan positif yang dikerjakan secara berulang sehingga mengerti, memahami, menghayati dan kompeten sesuai bidangnya. Pengalaman belajar dari aktivitas-aktivitas luar kelas maupun didalam kelas bahkan sampai di luar kampus.

Untuk membangun jiwa wirausaha bagi mahasiswa tentu diperlukan beberapa metode pembelajaraan yang efektif. Seperti Student Center Learning terutama menggunakan project based learning, agar mahasiswa mencoba untuk membuat suatu wirausaha dan mengasah jiwa wirausaha di dalam diri mahasiswa.Dosen harus mampu membangkitkan kreatifitas dan inovasi mahasiswa. Keterlibatan dan keterikatan mahasiswa dalam kegiatan belajar mengajar akan menggali nilai-nilai kreatifitas dalam diri mahasiswa. Metode ini diharapkan dapat dipahami, diserap, dimengerti dan dihayati oleh mahasiswa seperti pembukaan wawasan, penanaman sikap, pembekalan ilmu dan pembekalan pengalaman. 
Pembukaan wawasan diberikan dosen untuk membuka wawasan akan asam, manis, dan pahitnya berwirausaha. Seperti diskusi mahasiswa dengan menceritakan kesuksesan dan kegagalan usaha, atau juga mengunjungi suatu usaha atau perusahaan yang sukses pada masa ini.

Penanaman sikap wirausaha diberikan oleh dosen melalui keterlibatan mahasiswa untuk memasarkan produk yang dibuat masing-masing, mulai dari pembuatan produk sampai ke pemasarn di jalan Galuh - Karawang acara car free day setiap hari minggu sebagai tugas kuliah. Kebiasaan ini akan tertanam jiwa wirausaha bagi mahasiswa.

Pembekalan ilmu selalu diberikan oleh dosen di kelas dengan mengajarkan teori-teori kewirausahaan, Teknik pemasaran dan manajemennya. Diharapkan pembekalan ilmu ini dapat diterapkan ketika mahasiswa menjalankan sebuah usaha yang bukan ajang untuk coba-coba.

Penanaman pengalaman diberikan oleh dosen ketika diberikan tugas acara gebyar kewirausahaan. Dosen memberikan score nilai untuk penjualan terbanyak dan cara promosi pemasarannya. Keberhasilan atau pahitnya kegagalan menjadi pengalaman dan pembelajaran mahasiswa dimasa depan.

4) PelatihanKewirausahaan Mahasiswa

Pelatihan kewirausahaan mahasiswa merupakan peningkatan pengetahuan , keterampilan dan mental wirausahawan yang diperuntukan untuk mahasiswa, dengan tujuan mengenali, memahami, bangkit jiwa wirausaha serta minat untuk membuka usaha baru yang Tangguh.

Manfaat pelatihan kewirausahaan salah satunya menumbuhkan jiwa wirausaha, peningkatan pengetahuan dan kompetensi. Untuk saat ini pelatihan kewirausahaan di perguruan tinggi hanya sebatas kegiatan program kemahasiswaan, seminar, kerja praktek dan pembelajaran dikelas. Belum dilaksanakannya pelatihan kewirausahaan mahasiswa secara khusus dengan mendatangkan pakar atau pemateri untuk melakukan pelatihan kewirausahaan terutama program inkubator binis untuk membina dan mempercepat keberhasilan pengembangan wirausaha melalui permodalan, kemitraan bisnis, strategi pemasaran, informasi indurtri masa kini dan sebagainya uutuk menghasilkan profitabilitas .

5) Kerjasama Lambaga dalam kewirausahaan.

Menjalin kerjasama kemitraan dalam kewirausahaan diperlukan untuk menumbuhkan jiwa wirausaha. Seperti kerjasama Lembaga perguruan tinggi dengan lembaha pemerintah atau perusahaan. Tujuan kerjasama ini adalah untuk mengembangkan kemandirian dalam pembangunan serta adanya kontinuitas yang menguntungkan semua pihak dan berkeadilan atas dasar ekonomi kerakyatan.

Kerjasama Lembaga dalam kewirausahaan meliputi kerjasama dengan Dinas Perindustrian, Perdagangan, Pertambangan dan Energi Kabupaten Karawang. Kerjasama tersebut memuatpembinaan usaha mahasiswa, pengawasan dan pengendalian produk mahasiswa, peningkatan mutu produksi mahasiswa dan bentuk lain yang berkaitan dengan kewirausahaan mahasiswa.

Dinas Koperasi and UMKM Kabupaten Karawang juga menjalin kerjasama dengan perguruan tinggi seperti bidang binaan usaha, pengawasan dan peningkatan tatakelola serta penelitian kewirausahaan.

Kerjasama dengan perusahaan belum dilaksanakan dikarena mahasiswa belum dapat membuat produk sesuai dengan mutu pasar. Oleh sebab itu, diharapkan untuk 
kedepannya dibentuk program incubator bisnis untuk pengembangan produk mahasiswa yang sesuai dengan standar mutu perusahaan.

\section{b. Kendala Stakeholder Lembaga Pendidikan Dalam Meningkatkan Jiwa Berwirausahan}

terdapat kendala-kendala atau hambatan dalam perjalanan semua program perguruan tinggi untuk meningkatkan jiwa wirausaha mahasiswa. Berikut beberapa kendala dalam upaya meningkatkan jiwa wirausaha mahasiswa sebagai berikut:

\section{a. Partisipasi Mahasiswa}

Keterlibatan mahasiswa dalam kegiatan kemahasiswaan khususnya bidang kewirausahaan merupakan upaya peningkatan potensi diri mahasiswa dan sebagai unsur pembelajaran diluar kelas. Terkadang mahasiswa mengikuti kegiatan hanya untuk kesenangan belaka, seharusnya mahasiswa perlu memahami dan menghayati kegiatan tersebut untuk pembekalan mahasiswa di masa yang akan datang.

Hasil temuan dari penelitian menemukan kesamaan bahwa keaktifan mahasiswa dalam kegiatan kewirausahaan kurang diminati. Padahal pentingnya program kewirausahaan untuk masa depan mahasiswa jika ingin berwirausaha. Salah satu faktor ketidakikut sertaan mahasiswa dalam program tersebut dikarenakan tidak bisa membagi waktu untuk kegiatan. Mahasiswa biasanya terbagai menjadi dua, mahasiswa regular tidak bekerja dan mahasiswa regular yang bekerja. Mahasiswa yang bekerja lebih banyak tidak aktif dalam partisipasi kegiatan kewirausahaan. Namun tidak sedikit juga mahasiswa regular yang tidak mengikuti kegiatan mahasiswa, alasan mahasiswa ingin memilih menjadi seorang pekerja di perusahaan.

Faktor kedua mahasiswa tidak berpartisipasi dalam kegiatan wirausaha dikarenakan mahasiswa merasa malu dan gengsi untuk mejual produknya sendiri. Mahasiswa berpikir merasa gengsi atas statusnya untuk berjualan. Gengsinya itu adalah ketakutan mahasiswa diejek oleh rekan, teman, saudara dan lainnya.

Faktor selanjutnya tidak mengikuti kegiatan wirausaha yakni, mahasiswa malas untuk berwirausaha. Penyabab kemalasan mahasiswa salah satunya dikarena biaya hidup masih ditanggung oleh orang tua. Terutama mahasiswa regular tidak bekerja. Kebanyakan kemalasannya tersebut sudah nyaman akan keadaan sekarang karena semua kebutuhannya masih ditanggung oleh orang tua.

\section{b. Pola Pikir Mahasiswa}

Pola pikir merupakan kepercayaan yang ada pada dirinya atas suatu pandangan tertentu sehingga menyebabkan cara berpikir untuk menentukan sikap, pandangan, dan masa depan. Pola pikir mahasiswa pada umumnya ketika menyelesaikan kuliah hanya ingin menjadi seorang pegawai. Mahasiswa ingin mengejar status sosial yang aman, dan pekerjaan mapan. Setiap bulan gaji diterima dan rekeningan tabungan bertambah, maka itu yang diimpikan.

Pola pikir tersebut susah dirubah dengan cepat. Kebanyakan orang tua selesai kuliah mendapatkan pekerjaan yang dapat mengangkat drajat hidupnya. Mahasiswa yang sudah berpola pikir tersebut tidak bisa diajak untuk berwirausaha, kecuali sedikit-demi sedikit mindset mahasiswa diarahkan kea rah wiraswasta bukan bekerja, namun hal tersebut membutuhkan waktu yang cukup lama.

\section{c. Modal Usaha Awal}


Mahasiswa ketika sudah mendapatkan keilmuan wirausaha, praktek wirausaha, kreatifitas, inovasi, strategi pemasaran dan manajemen pengolahan mendapatkan kendala lainnya untuk memulai usaha yaitu modal awal. Apabila modal tidak ada kebanyakan mahasiswa akan mengurungkan niat berwirausaha sehingga jiwa usahanya menurun.

Padahal modal bukan faktor utama untuk memulai usaha, modal hanya faktor pendukung untuk mengembangkan usaha. Apabila mahasiswa sudah ingin memulai usaha bisa disesuaikan dengan kemampuan usahanya mulai dari skala kecil dan bekembang ke skala lebih besar. Berikutnya modal yang menjadi faktor pendukung utama dalam pengembangan bisnis.

\section{d. Biaya Kegiatan Kewirausahaan}

Program kegiatan yang telah dilakukan oleh pemangku kepentingan dalam pelaksanaannya tentu memerlukan biaya kegiatan. Kelancaran kegiatan kewirausahaan tergantung jumlah anggaran biaya yang tersedia. Pada kenyataannya anggaran biaya dibantu oleh Lembaga namun tidak mencukupi untuk proses kegiatan tersebut. Mahasiswa dan stakeholder mencari dana dengan swasembada dana mandiri. Contoh seperti penyelenggaraan seminar nasional. Sumber dana untuk seminar terutama pada harga tiket masuk, apabila tidak mencukupi maka mahasiswa dan stakeholder mencari sponsorship. Biaya kegiatan yang cukup besar tersebut merupakan salah satu faktor kendala dalam upaya meningkatkan jiwa wirausaha mahasiswa.

\section{e. Inkubator Bisnis}

Inkubator bisnis merupakan program dari suatu Lembaga untuk pembinaan mahasiswa dan pengembangan suatu produk bisnis melalui tahapan-tahapan pelatihan dan Pendidikan, permodalan, kerjasama kemitraan dan pemasaran produk dengan tujuan produk dapat dipasarkan.

Standar pelayanan inkubator perguruan tinggi meliputi layanan Pendidikan dan pelatihan, layanan penelitian dan akses penggunaan teknologi/informasi, layanan binaan dan konsultasi, layanan mitra kerjasama, dan layanan akses permodalan.

Pada saat ini perguruan tinggi dikabupaten karawang belum memiliki inkubator bisnis perguruan tinggi. Inkubator bisnis bukan hanya sekedar modal biaya pendirian dan sarana/prasana, namun perlu memiliki program kegiatan inkubator yang harus dikaji terlebih dahulu.

Demikian hasil pemaparan penelitian ini atas kendala yang dihadapi stakeholder perguruan tinggi dalam upaya menumbuhkan jiwa kewirausahaan mahasiswa pada tingkat perguruan tinggi se-kabupaten karawang khususnya prodi manajemen.

\section{KESIMPULAN}

Kesimpulan atas peran stakeholder dalam upaya meningkatkan jiwa wirausaha mahasiswa pada tingkat Pendidikan Tinggi prodi manajemen kabupaten karawang sebagai berikut:
a. Kurikulum Pendidikan Program Studi
b. Program Mahasiswa Kewirausahaan
c. Metode Pembelajaran Kewirausahaan
d. Pelatihan Kewirausahaan Mahasiswa
e. Kerjasama Lembaga dalam kewirausahaan. 
Terdapat kendala-kendala atau hambatan dalam perjalanan semua program perguruan tinggi untuk meningkatkan jiwa wirausaha mahasiswa. Berikut beberapa kendala dalam upaya meningkatkan jiwa wirausaha mahasiswa sebagai berikut:
a. Partisipasi Mahasiswa
b. Pola Pikir Mahasiswa
c. Modal Usaha Awal
d. Biaya Kegiatan Kewirausahaan
e. Inkubator Bisnis

\section{REFERENSI}

Alma, Buchari. 2010. Kewirausahaan untuk mahasiswa dan umum. Alfabeta. Bandung. Aris Subandono, Pengaruh Life Skill Diklat Kimia Produktif dan Prestasi Belajar Diklat Kewirausahaan terhadap Minat Berwirausaha pada Siswa SMK Kimia Industri Theresiana Semarang. Skripsi. FMIPA-UNES, 2007.

Bambang Banu Siswoyo, Pengembangan Jiwa Kewirausahaan di Kalangan Dosen dan Mahasiswa. Jurnal Ekonomi Bisnis (Nomor 2 tahun 14). Hlm. 114-123, 2009.

Bangsawan, Satria, dkk, Upaya Pengembangan UMKM Oleh Lembaga Keuangan dan Non-Keuangan di Provinsi Lampung. FE Universitas Lampung, 2006.

Geoffrey G. Meredith et al. (2002). Kewirausahaan: Teori dan Praktik. (Alih bahasa: Andre Asparsayogi). Jakarta: Penerbit PPM.

Hadi, Nur, Corporate Social Responsibility edisi Pertama. Yogyakarta : Graha Ilmu, 2011.

Kamus besar bahasa Indonesia. https/kbbi.web.id/jiwa

Kasmir, “ Kewirausahaan”, Jakarta : Rajawali Pers 2014.

Maman Suryamannim, Minat Berwirausaha pada Mahasiswa Pendidikan Teknik Elektro. Skripsi. FT-UNS, 2006.

Savitri, Citra., Wanta, Upaya Menumbuhkan Minat Berwirausaha Pada Mahasiswa Prodi Manajemen di UBP Karawang, Jurnal Manajemen \& Bisnis Kreatif, Vlo.3 No.1, 2017.

Suharyadi., Nugroho. A., Purwanto., \& Maman. F. Kewirausahaan Membangun Usaha Sukses Sejak usia Muda. Salemba Empat: Jakarta Suryana, Kewirausahaan. Jakarta: Salemba Empat, 2001.

Suryana, Kewirausahaan. Jakarta: Salemba Empat, 2014.

Suryana, Kewirausahaan: Pedoman Praktis, Kiat dan Proses Menuju Sukses. Jakarta:

Salemba Empat, 2008.Tim Penyusun Kamus, Kamus Besar Bahasa Indonesia. Jakarta: Balai Pustaka, 2007. Undang-Undang Dasar RI Nomor 9 Tahun 1995 tentang Usaha kecil

Services Marketing. Mc Graw Hill. New York.

Wibowo. 2013. Perilaku dalam organisasi. Jakarta: Raja grafindo persada 